Review

\title{
Criteria-Based Identification of Important Fuels for Wildland Fire Emission Research
}

\author{
Adam C. Watts * (D), Vera Samburova and Hans Moosmüller \\ Division of Atmospheric Sciences, Desert Research Institute, Nevada System of Higher Education, \\ 2215 Raggio Parkway, Reno, NV 89512, USA; Vera.Samburova@dri.edu (V.S.); Hans.Moosmuller@dri.edu (H.M.) \\ * Correspondence: Adam.Watts@dri.edu
}

Received: 15 May 2020; Accepted: 11 June 2020; Published: 16 June 2020

\begin{abstract}
Studies of the emissions from wildland fires are important for understanding the role of these events in the production, transport, and fate of emitted gases and particulate matter, and, consequently, their impact on atmospheric and ecological processes, and on human health and wellbeing. Wildland fire emission research provides the quantitative information needed for the understanding and management of wildland fire emissions impacts based on human needs. Recent work to characterize emissions from specific fuel types, or those from specific areas, has implicitly been driven by the recognition of the importance of those fuel types in the context of wildland fire science; however, the importance of specific fuels in driving investigations of biomass-burning emissions has not been made explicit thus far. Here, we make a first attempt to discuss the development and application of criteria to answer the question, "What are the most important fuels for biomass-burning emissions investigations to inform wildland fire science and management?" Four criteria for fuel selection are proposed: "(1) total emissions, (2) impacts, (3) availability and uncertainty, and (4) potential for future importance." Attempting to develop and apply these criteria, we propose a list of several such fuels, based on prior investigations and the body of wildland-fire emission research.
\end{abstract}

Keywords: biomass burning; combustion; emissions; fuels; fuel selection criteria; wildland fires

\section{Introduction}

\subsection{Terminology and Scope}

We use the terms "wildland" and "wildland fire", as defined by the National Wildfire Coordinating Group [1], with "wildland" referring to "An area in which development is essentially non-existent, except for roads, railroads, powerlines, and similar transportation facilities. Structures, if any, are widely scattered." and with "wildland fire" referring to "Any non-structure fire that occurs in the wildland". This terminology indicates a distinction between wildland fires and the use of open fires to burn agriculture waste or refuse. Although these and other biomass-burning emissions are of great importance to atmospheric sciences and public health, here, we concern ourselves with the relatively uncontrolled wildland fires that represent the dominant influence on ecosystems, the atmosphere, and people.

\subsection{Background of Fuels Classification}

The importance of wildland fire is recognized across most areas of earth and environmental sciences [2], due to its major societal, economic, ecologic, and human health and wellbeing impacts. Quantifying fire processes and effects, and their interaction with other, non-fire processes, is consequently the focus of much effort within many disciplines. Within the broad scope of wildland fire science, this effort has resulted in remarkable progress in predicting the behavior of wildland fires. 
The pioneering work of Rothermel [3] is widely regarded as having ushered in the age of numerical prediction of the movements of wildland fires, and, currently, many modeling schemes exist to forecast the growth of large fires $[4,5]$. Factors such as meteorology and its interactions with fires, and the contributions of radiation and convection determine fire dynamics [6] and control fire growth and movement to varying, but generally substantial degrees. Recognizing the dominant influence of fuels and their varying properties on the characteristics of wildland fires, wildland fire researchers have developed abridged fuel classification schemes that create broad categories of fuels across biomes and permit inputs to a variety of models designed to predict fire behavior and effects, and the production and fate of smoke and emissions. For example, Rothermel outlined 11 fuel types for input into his eponymous fuel-spread model [3]; Albini expanded on this work to generate 13 wildland fuels classifications [7]. A later, more complex scheme created and incorporated 40 fuel types [8]. All these systems have the goal of improving model predictions of fire behavior, particularly fire spread; they are therefore based on fuel characteristics, such as arrangement, rate of drying, and other factors that contribute to the ignition and spread of fires across fuel beds [9]. As such, they are largely focused on fuels important to the flaming combustion phase, while largely ignoring fuels that mostly burn in the smoldering phase [10]. A few fuel components, e.g., "Southern Rough" (e.g., "Southern Rough"; [7]) refer to geographic areas where substantial contributions by individual plant species (or groups of species) can be inferred. However, no fuel classification scheme exists to guide research that focuses on the properties of emissions produced by wildland fires either in North America or elsewhere [10].

\subsection{Importance of Fuels Prioritization for Emissions Research}

Investigations of the physics, chemistry, transport, fate, and effects of wildland fire emissions are collectively in a state of rapid growth, driven by needs for prediction of fire processes and effects and enabled by advances in experimental design [11-14], and in measurement and analysis technology [15-17]. In particular, societal needs for information concerning the effects of wildland fire emissions on air quality, visibility, and public health [18-21], and on global climate [22-24] and in return, the effects of human-caused landscape modifications and climate change on fire emissions [25,26], are promoting and influencing fire emission research [12].

The modeling of wildland fire emissions generally requires detailed, fuel-specific emission factors to quantify primary atmospheric emissions that can be used to assess the impacts of wildland fire emissions on global and regional climate, human health, regional air quality and visibility, and other areas [27,28]. Detailed databases giving unified access to the results from laboratory and field emissions studies (e.g., measurements of fuel-specific, fuel-based emission factors for speciated gaseous and particulate matter (PM) emissions) grow only slowly, due to the expensive nature of detailed emission studies, and the difficulties of presenting the results of very different studies in a unified manner [29-31].

The importance of accurately predicting wildland emissions means that the number of these studies for various types of wildland fuels continues to grow. For example, a Google Scholar search (conducted on 3 March 2020) for "laboratory fire emissions" yielded a near-exponential increase of the annual number of publications from 1985 (488 publications) to 2018 (12,200 publications) corresponding to a 25-fold increase in publication rate over this 33-year period. These studies are conducted in order to provide inputs for models addressing air quality, visibility, human health [19,32], and climate change $[33,34]$.

We contend that-due to the growing magnitude of effects from wildland fire emissions on climate and health in some regions of the globe [35] and resource constraints limiting the rate at which detailed emissions studies can occur-determining the most important wildland fuels for future emission research is needed, to guide future efforts in this area of work. We approach this goal with the objectives of (1) developing selection criteria and (2) applying these criteria to compile an initial list of important wildland fuels for experimental studies of wildland fire emissions. 


\section{Developing Criteria for Fuels Prioritization}

Here, we concern ourselves with the characterization of near-field emissions from the combustion of biomass in wildland fires, i.e., the smoldering and flaming combustion of live and dead vegetation and organic matter in the upper layers of soil-collectively known as wildland fuels. Unlike fuels classifications developed for other aspects of wildland fire, no scheme exists currently for assessing the relative importance of some wildland fuels over others with respect to combustion emissions. It is known that the emissions produced from the combustion of these fuels vary considerably as a function of fuel properties and environmental conditions [36], and a growing body of literature describes the types and relative quantities of emissions across a range of different fuels and varying characteristics within a single fuel type, e.g., arrangement, density, moisture (e.g., arrangement, density, moisture; [10]), as function of environmental conditions, e.g., temperature, relative humidity, wind velocity (e.g., temperature, relative humidity, wind velocity; [37]). Note that emissions and their toxicity are greatly dependent on the combustion phase (e.g., flaming, smoldering, [36]), which itself is a function of fuel and environmental conditions [38-41].

We first discuss two possible approaches (i.e., splitting vs. lumping) for creating a list of criteria, to identify priority fuels for combustion emission research that acknowledges the variety of effects from wildland fires on humans and on anthropogenic and natural systems. One immediate challenge facing such an effort is to include criteria reflecting the range of socio-cultural, human health, ecological, and climatic impacts, and to mitigate the varying quality and availability of data from around the globe. Indeed, the drive to better understand the influence of wildland fire emissions on these factors is the very reason that a first-order prioritization of important fuels is so challenging. This is followed by discussion of an initial list including the criteria of (1) total emissions, (2) impacts, (3) availability and uncertainty, and (4) potential for future importance.

\subsection{Splitting Versus Lumping: Two Possible Approaches}

For developing inventories of combustion emissions data for wildland fuels, two divergent approaches immediately become apparent. The first is to select individual components of a "fuelscape" - the fuels found in an ecosystem or landscape of interest-and consider each individual species, and even the variety of plant parts within a species-foliage, bark, small or large branches, litter, and so on-and to quantify the emissions characteristics for each of the many environmental factors known to affect combustion, as mentioned above. Here, the assumption is that during the combustion of a fuelscape, total emissions can be calculated with a properly weighed sum over its combusted components. However, we are not aware of any verification of this assumption for realistic fuelscapes. For the purposes of this study, we refer to this approach as "splitting."

A contrasting approach considers all of these major elements together, burning an arrangement including the major plant species and their component parts together with litter, duff, and soil-i.e., an approach that "lumps" together all of the constituents of a wildland fuelscape. Such an approach aims to ensure that the fuel arrangements and combustion processes comprise those found in a given fuelscape and assumes that the combustion products from such an arrangement qualitatively reflects those found in nature, by being represented in laboratory emissions profiles from that fuelscape.

Ideally, emissions from wildland fuel combustion would be assessed across a variety of variables known to influence combustion and emissions, both fuel properties (e.g., arrangement, density, moisture) and environmental conditions (e.g., temperature, relative humidity, wind velocity) - just as Rothermel [3], Albini [7], and others have done-to develop and refine fuels classification systems for fire-behavior models. Additionally, individual plant species within a vegetation community or portions of organic soil horizons (e.g., Oa, Oe, Oi, or otherwise according to factors such as mineral content, depth, or other determinants of combustion), would also be analyzed, due to their known differences in combustion dynamics and emissions produced; these differences certainly can be expected to extend to the various components of individual plants, since leaves, small and large branches, bark, and stems 
all should be expected to vary chemically and physically in their combustion emissions as they do in vivo (as well as in mortem).

Alternatively, a "lumping" approach for fuels selection should capture the variation found in an ecosystem, community or region, and ensure that its major components are represented, in order to ensure that at least the identities of emissions species (of both gaseous and particulate) are discovered in analysis, even if their relative abundance is acknowledged to vary with a number of fuel characteristics. The moisture content, arrangement, density, and combustion phase should represent those conditions realistically encountered under a scenario of a wildland fire in a given area, for similar reasons. Such characterizations can support management decisions and the study and prediction of climate and health impacts when emissions occur from broad fuel types, and the effects and interactions of emissions with the atmosphere can be compared across the biomes from which they originate. The essence of this approach is to ensure that all emissions constituents created by wildland fires in a given area are identified, and to some degree also quantified.

Both the "splitting" and "lumping" approaches have their benefits and drawbacks. In addition, both approaches suffer from the uncertainty of scaling emission factors with fire size, from small-scale laboratory fires to mega fires. This has led to concerns in the biomass-burning-emissions community, regarding the ability of laboratory-based experimental burns to accurately replicate conditions and emissions observed in real wildland fires, e.g., [42-44], and in-depth understanding of scaling laws and atmospheric processes may be necessary for laboratory-based methods to yield accurate quantitative extrapolations to wildfires. Therefore, the usefulness of either approach may be limited for deriving quantitative biomass-emissions estimates for real-world wildfires.

Examining the emissions of individual fuelscape components under varying combustion environments could support the development of tools to precisely predict the production of many combustion products from wildland fires, especially in situations where the constituent elements of a burned area are well-characterized or can be readily reconstructed. Additionally, powerful forecasts of changes to wildland fire emissions could rely on data resulting from this approach, giving a picture of changes under scenarios of changes to climate, hydrology, fuel loads and composition, and many other factors for well-characterized landscapes. However, the advancements yielded by this approach would be both slow and resource-intensive, because achieving a comprehensive characterization of even a low-diversity plant community would require many combustion experiments per plant species-even multiple trials for each part of a plant-as other factors affecting combustion chemistry are varied, (e.g., [45,46]). In addition, the splitting approach ignores the combustion interactions between different components as they burn next to each other, exchanging energy and influencing each other's emissions.

By contract, the "lumping" approach prioritizes acknowledges that our understanding of emissions from wildland fires in large parts of the world remains limited and prioritizes expediency in addressing this first-order deficiency. Additional problems of the "lumping" approach include the limited ability to reproduce spatial fuel arrangements found in the wild in the laboratory. This is especially true for tall fuelscapes, including fuel ladders [47].

Ultimately, the splitting approach-the detailed characterization of emissions at the fine scale of individual fuel constituents and their variation - will tell us much more than coarse-scale estimates using the lumping approach, enabling the prediction of changes to emission impacts as a function of changes in fire regimes and climate. As emissions-characterization research advances to produce more comprehensive inventories and analysis costs are reduced, and as fire models advance in their ability to ingest an increasing resolution of fuel constituents and combustion environments toward yielding more detailed emissions-products data, the splitting approach will become a more useful means to providing highly quantitative information on biomass combustion emissions. However, fine-scale emissions studies achieve their results at the expense of applicability across large areas; and we argue that the value of such an approach in supporting atmospheric science research at large spatial scales is presently subordinate to gaining a first approximation of representative emissions, and their variation, from areas where wildland fire emissions have the greatest impact on the factors mentioned above. 
For the splitting approach to be truly useful for large fires, more knowledge on scaling issues [48,49] and on the interactions between multiple adjacent combustion processes is needed.

Here, we propose and present a prioritization of ecologically representative assemblages of wildland fuels, which below we refer to as wildland fuels, or simply fuels. These assemblages and their prioritization can be used for studies both utilizing the splitting and the lumping approaches.

\subsection{Total Emissions}

The first step in determining whether a given fuel assemblage is important for emission research is, generally speaking, to determine the relative emission contribution of wildland fires in that assemblage to total wildland fire emissions. A logical first step is to choose candidate fuels from among a list of those whose combustion emissions are among the highest. These emissions occur in gaseous and particulate forms, and estimates of these emissions at regional to global scales are generally made using remote sensing techniques, often deployed from satellites for near-global coverage [50]. In these cases, emission estimates are provided on the basis of their origin at a range of spatial scales up to the subcontinental, e.g., the Global Fire Emissions Database (e.g., Global Fire Emissions Database; [51-53]); however, data on wildfire occurrence and land cover information allow these emissions to be assigned to a particular biome, land cover class [54], and, in some cases, even individual fires or clusters of fire activity in a particular ecosystem [55]. Emissions of one type measured remotely or directly can be combined with known fuel-based emissions factors [31] for ecosystems, biomes, or fuels, to provide estimates of a variety of emissions classes, such as C [56] or N [46], and entire satellite data archives refined with these data and modeling can be used to estimate continental-scale emissions over several decades [57]. Laboratory and small-scale field combustion experiments contribute to libraries of additional trace gases and particulate matter [58] that can be used to refine these estimates.

\subsection{Impacts}

The impacts of emissions from wildland fires occur across the breadth of disciplines that consider fire, including human health, economics, biogeochemistry, and climate science. Within these disciplines, useful metrics for choosing important fuels include assessments of human health $[32,59,60]$, economic impacts [61-63], and atmospheric radiative forcing potential of emissions [24,52,64,65]. Where information allowing quantitative comparisons of impacts may be difficult to obtain, substitute metrics might be considered. For example, the economic and human health impacts of wildfires may be more easily quantified for some areas than for others, and direct impacts are more easily estimated than indirect impacts.

Due to a lack of consistently detailed information on fire impacts, data on area burned $[51,53,66]$ can provide useful indications of biomes and fuel types in which fires cause substantial impacts, especially when these data are combined with human population density [61]. However, these data generally are derived from orbital platforms [67], which can lead to inaccuracies resulting from cloud cover and limitations in detecting and characterizing smaller fires [68].

\subsection{Availability and Uncertainty}

Emissions and impacts are obvious criteria in attempting to list and rank potential fuels for investigation. However, we propose that additional criteria, much less difficult to quantify, are important to include. One of these is the degree to which prior emission research has been undertaken for a particular fuel or fuel assemblage, or the existence of studies whose findings would complement emissions characterizations and expand understanding of a fuel and its role across atmospheric and other elements of fire sciences. This criterion promotes the possibility for further work to complete a characterization of a fuel or fuel assemblage begun by others, so that comprehensive studies, for a given landscape, already begun might thus be enhanced. As techniques for emissions characterization become more economical, and as continued investigations reveal a need for high-resolution studies detailing the contribution of individual components within a fuel assemblage-progressing toward a 
"splitting" strategy—these studies will provide important foundations and guidelines. We refer to this criterion as the availability of detailed emissions characterization research.

We further propose to include under this criterion opportunities that ongoing campaigns will provide to investigate emissions from wildland fires. Currently, one of the most significant of these is the Fire and Smoke Model Evaluation Experiment (FASMEE), which was developed to improve fire and smoke models using a series of large prescribed fires $[12,13,69]$. Other recent or ongoing campaigns, such as WE-CAN [70], and FIREX-AQ [71], can leverage information from laboratory or field-based biomass-emission studies, where fuels are explicitly identified and measured, and thereby both benefit from and contribute to the selection of specific fuels according to this criterion.

It should be noted that despite considerable progress in fire ecology, and the discipline's contribution to our understanding of fire impacts on ecosystems and non-human species, there does not yet exist sufficiently broad information on these impacts to support a robust global intercomparison of the fuels in the systems that have been examined. Added to this deficit is the difficulty of reconciling the negative ecological impacts of fire occurrence [72] or alteration in severity [73-75] with those related to its suppression, collectively considered as topics related to altered natural fire regimes. Owing to the results of studies in various well-characterized ecosystems, however, some fuels can be contributed for consideration in a list of important fuels. The purpose in doing so is to begin forming a comprehensive understanding of the multifaceted role of wildland fire, as it simultaneously influences vegetation, hydrology, atmospheric processes, and linked atmospheric-terrestrial cycles, such as carbon dynamics. Therefore, in addition to availability, we also propose that a situation can exist whereby the need for emissions data for a given fuel exists, but little or no prior work on such a fuel has been undertaken. We propose that uncertainty, for a given wildland fuel, can also create a need to prioritize that fuel for inclusion in future studies, and we therefore include it as a facet of this criterion.

\subsection{Potential for Future Importance}

Anthropogenic and other changes in climate will continue to manifest as changes to wildland fire activity in many parts of the world through the 21st century [76-79]. These changes may be driven by increases in fuel amount via net primary productivity growth, fuel availability by changes to nighttime temperature and humidity and drought dynamics, changes to human land-use patterns, and lengthening fire seasons in areas where the onset of spring snowmelt and autumn snow govern fire activity. While climate change is likely to affect all global ecosystems to some extent, the degree to which climate change will alter fire activity, and the resulting impacts, varies at sub-continental scales [80]; see also [81] for a discussion of interactive climate, atmospheric $\mathrm{CO}_{2}$, and human population effects on emissions from wildfires. Acknowledging the absolute and relative values of projected changes to fire activity and impacts, under likely scenarios of altered climate, provides a way to identify fuels whose importance to biomass emission research will rise in the coming decades. We finally propose the inclusion of the potential for future importance as a criterion for selecting wildland fuels.

\section{Applying the Criteria}

\subsection{Magnitude of Carbon Emissions}

For recent and historical emissions of gases and PM, we used the Global Fire Emissions Database (GFED) [52], Wildland Fire Emissions Information System (WFEIS) [28], and the Global Fire Atlas [82], along with a number of recent studies on global and regional emissions from wildland fires as sources for information to produce candidate fuels for inclusion [64,83-99]. These resources differ in scope and scale: GFED provides global assessments of fire emissions using satellite data on burned area, vegetation productivity, and overall $\mathrm{C}$ emissions, as well as some trace gas and aerosol emissions, with specific emissions factors applied $[27,58,100]$ to provide estimates of individual emission components at the subcontinental, biome scale. WFEIS uses burned-area maps from 1984 to the present, including the same Moderate Resolution Imaging Spectroradiometer (MODIS) satellite data products on burned 
area [66] as GFED, fuel loading (i.e., biomass) from the USDA Forest Service's Fuel Characteristic Classification System (FCCS) [FCCS, 9], and fuel consumption models from CONSUME [101] to produce emissions estimates by year for each of several different ecoregions for the Continental USA and Alaska.

Nearly $1.5 \times 10^{7}$ ha of boreal forest may burn every year [34], representing 151-202 $\mathrm{Tg}$ of C emissions annually, compared with global averages of $936 \mathrm{Tg} \mathrm{C}$ from forests and $3950 \mathrm{Tg}$ from global biomass burning [100]. Russia contains about two-thirds of the world's boreal forests [34], and $30 \%$ of the world's $C$ is in boreal zone forests [102,103]. $1.2 \times 10^{7}$ ha of boreal forests burn in Russia annually [34], while Kasischke et al. [104] estimate $4 \times 10^{6}$ ha burned in non-Russian boreal forests. Van der Werf et al. [52] estimated that during 2001-2009, most C emissions (44\%) were from grassland and savanna fires, while an additional 36\% came from fires in tropical forests and extratropical forest fires contributed $15 \%$. Kasischke et al. [105] estimate average total C emissions were 106-209 $\mathrm{Tg} \mathrm{yr}^{-1}$ between 1995-2003 from boreal forests and high-latitude peatlands. An updated emissions intercomparison study by Andreae [58] found tropical forests and savanna-grassland fuels to contribute the highest amounts of total emissions from biomass fires in these ecosystems. These prior studies indicate a consensus for recommending wildland fuels from tropical forests, boreal forest ecoregions, high-latitude peatlands, and grasslands and savannas—especially African savanna fuels (due to the quantity of emissions from fires in these ecosystems [106])—for emissions research, as indicated in Table 1.

Table 1. Five examples of wildland fuels considered according to the "Magnitude of fire emissions" criterion. Fuels are listed with dominant or common global locations of occurrence, and information on total emissions (generally either total $\mathrm{C}$ or $\mathrm{CO}_{2}$, depending on source).

\begin{tabular}{cccc}
\hline $\begin{array}{c}\text { Fuel Type (Biome, } \\
\text { Community, Source) }\end{array}$ & Location & Emissions ${ }^{\mathbf{1}}$ & References \\
\hline Tropical Forest & S. America, Africa & $4670 \mathrm{Tg} \mathrm{yr}^{-1} \mathrm{CO}_{2}$ & {$[52,58,106]$} \\
\hline Savanna/Grasslands & Sub-Saharan/Southern Africa & $3980 \mathrm{Tg} \mathrm{yr}^{-1} \mathrm{CO}_{2}$ & {$[52,58,82,83]$} \\
\hline Boreal Forest & Russia, Canada, Alaska USA & $690 \mathrm{Tg} \mathrm{yr}^{-1} \mathrm{CO}_{2}$ & {$[34,52,82,100,105]$} \\
\hline Temperate evergreen forests & NW USA/SW Canada & $470 \mathrm{Tg} \mathrm{yr}^{-1} \mathrm{CO}_{2}$ & {$[52,58,100]$} \\
\hline Peatlands & Russia; N. Europe, N. America, SE Asia & $270 \mathrm{Tg} \mathrm{yr}^{-1} \mathrm{CO}_{2}$ & {$[52,55,58,105]$} \\
\hline $\begin{array}{l}1 \\
\text { Where emissions from a given fuel are provided in multiple literature sources, the source supplying the figure } \\
\text { provided in the table is listed first, followed by additional sources providing additional estimates or further } \\
\text { information on combustion emissions from the fuel. }\end{array}$ &
\end{tabular}

\subsection{Impacts of Fire Emissions: Economic and Regional Air Quality and Public Health}

Our consultation of published studies generated candidate fuels for inclusion based on impacts to economies, and regional air quality and public health (Table 2). These impacts result from the generation of large amounts of aerosols in proximity to human population centers, especially primary and secondary $\mathrm{PM}$ and $\mathrm{O}_{3}$ from $\mathrm{NO}_{x}$ and VOC emissions $[107,108]$. These studies found large amounts of particulate matter (PM) emitted as a result of burning in temperate evergreen and boreal forests [31], and of $\mathrm{O}_{3}$ produced in regions comprising tropical forests and peatlands, grasslands, and savannas in sub-Saharan Africa, and boreal forests [108]. Acute health and economic impacts resulted from the emissions of fires in chaparral, eucalypt, and temperate evergreen forests; the impacts of wildfires in chaparral and eucalypt forests on human life and property is especially noteworthy in recent years in Australia, California USA, Spain, and Portugal [57,59,63,109-111], where eucalypt and chaparral-type vegetation communities dominate. A combination of high human population density in Southeast Asia and the production of high amounts of PM from fires in the tropical peatlands occurring in this region [112-114], mean that high impacts to air quality are associated with significant human health risks resulting from these fires [115-117]. Finally, Johnston, et al. [20] noted high levels of human health impacts from fires in regions of South America and sub-Saharan Africa dominated by tropical forests. 
Table 2. Examples of wildland fuels whose emissions cause sufficient impacts to air quality and public health to merit priority consideration for biomass burning emission research.

\begin{tabular}{ccc}
\hline Fuel Type (Biome, Community, Source) & Location/Region of Impact & References \\
\hline Tropical Forest & S. America, Africa & {$[20,52,58,106]$} \\
\hline Savanna/grasslands & Sub-Saharan/Southern Africa & {$[20,52,58,83]$} \\
\hline Peatlands & Russia; N. Europe, N. America, SE Asia & {$[52,55,58,105,108,112-114]$} \\
\hline Temperate evergreen forests & NW USA/SW Canada & {$[52,58,100,109]$} \\
\hline Mediterranean and N. American Chaparral & Mediterranean Europe; California USA & {$[59,60,63,110]$} \\
\hline Eucalypt Forest & Australia; Portugal & {$[110,111]$} \\
\hline
\end{tabular}

\subsection{Availability/Uncertainty}

Comprehensive, detailed emission characterizations are available from a number of prior studies for several wildland fuels. These include several wildland fuels from North America: the Northwestern USA, Southwestern USA, and Southeastern USA coniferous forests; boreal mixed-conifer forests, and chaparral [27,118-121] (see also [30,31,45,122-134] for multiple examples of output from the Fire Laboratory at Missoula Experiment (FLAME) that resulted in the characterization of emissions from numerous fuels during successive campaigns). Considerable experimentation has occurred on smoldering combustion emissions in tropical and high-latitude peats, resulting in a rich library of information concerning peat soil combustion emissions across biomes $[29,55,135-142]$, which can be combined with information on hydrologic and ecological effects [40,143-145], as well as laboratory studies of the physics and dynamics of smoldering combustion to achieve a multifaceted understanding of peat fire dynamics, impacts, and effects [146-150]. Thus, in addition to wildland fuels collected from tropical and high-latitude peatlands, commercial Irish peat is included in this list, because the level of prior characterization for this biomass fuel makes it akin to a benchmark for emissions studies in peat [151]. For similar reasons, emission research efforts also should focus on fuels from fires at the heart of large, coordinated campaigns such as FASMEE [13], WE-CAN [70], and FIREX-AQ [71]. In some instances (e.g., FASMEE), characterization of fuels in burn units is an integral part of study designs linking fuels, fire behavior, and smoke movement and chemical evolution [13]. In others, an emphasis on the airborne chemical measurements of wildland fire smoke means that more attention to the nature and characteristics of the fuels and combustion regimes that produce them will improve the applicability of results.

At the other extreme, application of emissions and impacts criteria may initially suggest a given fuel type which the literature surveys reveal to be poorly characterized, or even not investigated at all. Stockwell [152] highlights the problem of undersampled, yet globally significant, wildland fuels. Combined uncertainties in consumption and detailed emissions information imply difficulties in projecting fire impacts for some regions; these uncertainties appear to be particularly high in boreal forests $[153,154]$. Meanwhile, the widespread practice of wildland fuels mastication, meant as a means of reducing fire growth and risk in some areas [155], has led to the rapid development of a novel type of biomass fuel widespread in areas prone to wildland fires: fractured, relatively dense fuel particles whose tendency to undergo sustained combustion differs markedly from its original constituents [156]. Although fire behavior and effects in masticated fuels have been studied in the laboratory and field [157-159], the growing use of mastication as a fuels treatment combined with the tendency of treated areas to lie near population centers, and in regions where high population density and high fire activity coincide, indicate that this fuel type should be considered for future emissions research. Finally, in the USA prescribed fires are an important land-management strategy for maintaining ecosystems and reducing undesirably high fuel loads, and also constitute an important category of wildland fire. Furthermore, prescribed fires often are conducted in areas with significant human population density, such as the Southeastern USA, where the widespread occurrence of fire-dependent ecosystems also has led to considerable research on the effects of fire on their dominant 
species and ecosystems. As a result of the high amount of $\mathrm{PM}_{2.5}$ emitted from these areas [97,120], the inclusion of these fuels is warranted, even though prescribed fires are anthropogenic in nature (and also consume wildland fuels, the focus of this effort). A summary of fuels for consideration according to either multifaceted characterization and availability of comprehensive information, or the existence of other non-emissions characterization that would be complemented by the investigation of these fuels in emissions studies, is listed in Table 3.

Table 3. Wildland fuels listed below have been well-characterized in regards to growth, behavior, and effects of fires, or in other aspects of their combustion emissions and, consequently, additional work for which may complete a comprehensive picture; alternatively, this list also includes fuels for which little emissions research has been carried out, but where other factors indicate a need for such work to be performed.

\begin{tabular}{cccc}
\hline $\begin{array}{c}\text { Fuel Type (Biome, } \\
\text { Community, Source) }\end{array}$ & Location & Characterization Type & References \\
\hline Boreal and tropical peat & $\begin{array}{c}\text { Russia; N. Europe, } \\
\text { N. America, SE Asia }\end{array}$ & $\begin{array}{c}\text { Laboratory (Emissions); } \\
\text { Field (Ecological) }\end{array}$ & {$[55,104,135-145]$} \\
\hline Mixed-conifer & $\begin{array}{c}\text { Northwestern USA; } \\
\text { Southern Rocky } \\
\text { Mountains/Wasatch USA }\end{array}$ & $\begin{array}{c}\text { Laboratory (Chemical); } \\
\text { Field (Physical, Ecological) }\end{array}$ & {$[13,30,119]$} \\
\hline Commercial Irish Peat & Ireland & Laboratory (Physical) & {$[146-150]$} \\
\hline Masticated fuels & Worldwide; N. America & Laboratory (Physical) & {$[155-159]$} \\
\hline $\begin{array}{c}\text { Southeastern } \\
\text { (“Southern Rough”) }\end{array}$ & SE USA & $\begin{array}{c}\text { Laboratory (Physical, Chemical); Field } \\
\text { (Physical, Chemical, Ecological) }\end{array}$ & {$[98,121,160]$} \\
\hline
\end{tabular}

\subsection{Future Potential}

To apply our criterion of potential emissions, we used studies indicating the potential of certain regions to experience increases in fire activity corresponding to the likelihood of greater emissions or their impacts. In Table 4, we list five examples of fuels from regions where increases in fire activity or impacts are projected to occur. In general, changes to wildland fire activity projected for the next several decades are mainly due to factors related to climate change, with warmer and drier conditions leading to longer fire seasons, increased in area burned [161], and increased fuel consumption (and therefore greater emissions) for areas especially in mid- to high-latitude regions [79]. Notably, these regions include: (1) the western USA [76,77,162,163], comprising areas of conifer, mixed-conifer, chaparral, and shrubland; (2) Australia [164,165], comprising vast grasslands and eucalypt forests; and (3) boreal regions with their vast forests [33,34,166-169]. Ecosystems in these regions include peatlands which will be subject to increased fire activity and $C$ release due to climate factors; peatlands in low-latitude regions are more likely to experience increased fire activity, due to anthropogenic factors, such as draining and swidden agriculture methods [170]. Peatlands contain between one-fourth and one-third of the world's terrestrial carbon, and when burned release the vast amounts of $C$ that have been accumulated over centuries to millennia, compared to other fuels which represent $C$ sequestered over years to decades [55,171-173]. As a result of their C pool size and age, and the potential for increased contribution to emissions in the future [174,175], it is therefore important to consider these fuels as well. Finally, the same anthropogenic factors likely to be responsible for increased tropical peatland fire activity are at work in the tropical forests of Africa and the Amazon [176-179], with their effects on fire activity, emissions, and impacts likely to increase [180-183]. Due to the vast area of these forests and the amount of potential C release from fires in these ecosystems, emissions work including fuels representative of the Amazonian and sub-Saharan rainforests will help to inform projections of future effects of their emissions on global climate, regional processes such as cloud formation, and public health in rapidly-developing cities and suburban areas of the global tropics. 
Table 4. Fuels whose contribution to total emissions, impact on climate, human populations, or regional or global processes is likely to increase in the future are listed below.

\begin{tabular}{cccc}
\hline $\begin{array}{c}\text { Fuel Type (Biome, } \\
\text { Community, Source) }\end{array}$ & Location & $\begin{array}{c}\text { Type of/Reason for } \\
\text { Projected Increase }\end{array}$ & References \\
\hline Tropical Forest & S. America, Africa & $\begin{array}{c}\text { Climate-driven fire activity; } \\
\text { Land-use changes }\end{array}$ & {$[170,176-183]$} \\
\hline Boreal and tropical peat & $\begin{array}{c}\text { Russia; N. Europe, } \\
\text { N. America, SE Asia }\end{array}$ & $\begin{array}{c}\text { Climate-driven fire activity; } \\
\text { Land-use changes }\end{array}$ & {$[79,174,175]$} \\
\hline Boreal Forest & $\begin{array}{c}\text { Russia, Canada, } \\
\text { Alaska USA }\end{array}$ & Climate-driven fire activity & {$[33,34,79,166-169]$} \\
\hline Mixed-conifer & Western N. America & Climate-driven fire activity & {$[26,76,77,162,163]$} \\
\hline Eucalypt & Australia & Climate-driven fire activity & {$[164,165]$} \\
\hline
\end{tabular}

\subsection{Results of Joint Application of the Criteria}

When all criteria, discussed above for potentially selecting wildland fuels, are considered, a number of fuels are indicated as potentially important according to multiple criteria. Although quantitative comparisons across multiple criteria are impractical for a number of reasons, a simple means of compiling priority fuels is to consider those whose importance lies across multiple criteria. Table 5 summarizes the globally important fuels for biomass-burning emission research we have identified according to the criteria and information sources above and represents our generally recommended list of priority wildland fuels.

Table 5. The wildland fuels listed below represent the application of multiple criteria (Emissions, Impact, Availability/Uncertainty, and Potential).

\begin{tabular}{|c|c|c|c|}
\hline Biome & Location & Criteria & References \\
\hline Boreal Forest & Russia, Canada, Alaska USA & $\begin{array}{c}\text { Emissions; Impact; } \\
\text { Availability; Potential }\end{array}$ & $\begin{array}{c}{[28,33,34,52,79,100} \\
102,104,105,166-169]\end{array}$ \\
\hline Peatlands (Boreal) & Russia; N. Europe & $\begin{array}{c}\text { Emissions; Impact; } \\
\text { Availability; Potential }\end{array}$ & $\begin{array}{c}{[28,52,105,138,141} \\
143,144]\end{array}$ \\
\hline Peatlands (tropical) & SE Asia & $\begin{array}{c}\text { Emissions; Impact; } \\
\text { Availability; Potential }\end{array}$ & $\begin{array}{c}\text { [112,115-117,138,139, } \\
141]\end{array}$ \\
\hline Savanna/grasslands & Sub-Saharan Southern Africa & $\begin{array}{c}\text { Emissions; Impact; } \\
\text { Availability; Potential }\end{array}$ & {$[20,58,82,83,106]$} \\
\hline $\begin{array}{c}\text { Temperate evergreen } \\
\text { forests }\end{array}$ & NW USA/ SW Canada & $\begin{array}{c}\text { Emissions; Impact; } \\
\text { Availability; Potential }\end{array}$ & {$[52,58,100,109]$} \\
\hline Tropical Forest & S. America, Africa & $\begin{array}{l}\text { Emissions; Impact; } \\
\text { Potential }\end{array}$ & $\begin{array}{c}{[20,52,58,106,170,} \\
176-183]\end{array}$ \\
\hline Chaparral & $\begin{array}{c}\text { California USA; } \\
\text { Mediterranean Europe }\end{array}$ & $\begin{array}{l}\text { Impact; Availability; } \\
\text { Potential }\end{array}$ & {$[57,59,63]$} \\
\hline Eucalypt Forests & Australia; California USA & Impact; Potential & $\begin{array}{c}{[52-54,59,110,111,} \\
164,165]\end{array}$ \\
\hline $\begin{array}{c}\text { Southeastern } \\
\text { ("Southern Rough") }\end{array}$ & SE USA & Availability; Potential & {$[16,98,119-121]$} \\
\hline Masticated Fuels & $\mathrm{W}$ and SE USA & Availability; Potential & [155-159] \\
\hline Commercial Irish peat & Ireland & Availability & {$[146,148-151]$} \\
\hline FASMEE fuels & Utah USA; SE USA & Availability & {$[12,13,136,137,142]$} \\
\hline
\end{tabular}




\section{Discussion}

Translating this list of proposed important fuels for wildland fire research to practice amid the reality of finite resources will expose the experimenter to the complex balance of achieving deep, statistically robust (i.e., well-replicated) datasets versus breadth (representation of the range of moisture levels, physical arrangement, and variations in composition), as described above.

By focusing attention on a relative few, important assemblages of wildland fuels, we expect that these findings will be useful in a number of ways. First, investigators or teams in the areas of atmospheric chemistry and physics lacking a strong background in wildland fire science may find value in our list, since previously there has been relatively little information, other than expert opinion, to guide the selection of wildland fuels for emissions studies. Second, a common list of important fuels may lead to the rapid accumulation of emission information to serve as a foundation for more detailed studies (splitting) within a broader fuel assemblage. Lastly, we hope that our proposed list of criteria stimulates debate and discussion concerning those factors that determine importance, and that our attempt to prioritize fuels for emissions studies may inspire similar efforts in other disciplines, in the same way that our work has been inspired by the efforts of Rothermel and other pioneers of fire science to classify wildland fuels.

Further, our experiences suggest that lacking a wider set of guidelines, the progress of wildland fire emission research is unnecessarily slowed while researchers occasionally work on some "clusters" of closely related fuel types, while leaving others, seemingly of importance, relatively ignored. It is our hope that a first attempt to move toward a widely-recognized list of high-priority wildland fuels will help increase the availability of globally important wildland fuels emission data, thus improving our collective ability to support large-scale estimates of the interactions of wildland fires with climate, the atmosphere, and human society.

\section{Refining the Criteria for Future Use}

Despite its initial appearance of simplicity, the question, "Which are the most important fuels to use for emission research?" easily becomes a difficult topic. This difficulty is partly due to the varying amounts and types of data that can be used in efforts to answer the question, while applying criteria as different in their nature as health impacts and radiative forcing is a strategy destined for contentious debate. In this effort, we have proposed a list of criteria by which the constellation of wildland fuels can be judged. While we deem those fuels selected in their application to be "important," we do so in full recognition that the criteria should vary according to the emphasis of a given study, even over time, such a list of criteria and the results of their application will differ with changing fire regimes, climate, and patterns of human population growth, as well as the perceptions and values that continue to shape humanity's ancient relationship with fire. A greater objective than the resulting list of important fuels above has been to propose a framework to unify fuels selection in fire emissions research, and it is in this area we hope our efforts will prove to be least ephemeral.

Previous investigations on the emissions from wildland fuels have cited model inputs for fire management, atmospheric smoke transport, and climate, or public health, as justifications; hence, a number of candidates have been implicitly introduced as criteria to be used in determining which wildland fuels should be chosen over others when devoting limited resources to the characterization and study of their emissions. However, to date, no explicit effort has been made to organize criteria that should be used for evaluating and prioritizing wildland fuels for emission research. We believe this effort is the first attempt to do so, and as with many such efforts, we acknowledge that the presentation of these criteria is likely to stimulate discussion, and perhaps disagreement regarding the ones we present here, and the proposal of new ones. These outcomes are among our intended outcomes from this initial effort, and we look forward to the further development of this initial effort by the wildland-fire emission community as this field continues to develop rapidly.

While a number of additional or alternative criteria for evaluating and prioritizing wildland fuels for emission research can be envisioned, we chose to keep the list of selection criteria to a relative few. 
One major reason to exercise care in the type of criteria chosen results from the variety of scope and scale of the various analyses and outputs available for use in applying these criteria: the differences between GFED and WFEIS indicated above, for example, could lead to selection bias in favor of fuels located in areas covered by a lower-area but higher-resolution analysis, for example, potentially resulting in over-representation from areas studied more extensively (for example, fuels and their emissions from North America appear extensively studied, compared to those from Africa.). Already, the criteria of human impact leads to relatively narrow geographic focus on eucalypt fuels from Australia or chaparral fuels from California, USA for example; the likelihood that others may identify other candidates that could have been chosen in addition or instead of these will illustrate the reasons for our choice.

\section{Conclusions}

For the near future, the cost and difficulty of characterizing emissions will continue to limit the ability of these studies to estimate the impact of the above factors and their variations on emission products. Over time, improvements to technology and ever-growing datasets will enable greater exploration of factors influencing emissions; this work will include not only such fine-scale factors as those above, but it will also allow for work on fuel assemblages (e.g., varieties of species compositions and architectures). Therefore, the work we present here-to identify schemes for prioritizing fuels upon which researchers should focus-should experience evolution, and each major development in this area should prompt the re-examination of both the criteria and fuels themselves. For instance, large campaigns integrating fuels and emission measurements from the field with laboratory work can drive especially rapid progress when they incorporate high-resolution information on fuel composition, characteristics, and links between combustion conditions and chemistry, e.g., [121,184]. Efforts by the research community to support such efforts by bolstering existing studies of emissions from their constituent fuels, and to provide comprehensive research on other priority wildland fuels such as those we propose here, will provide an accelerating influence.

Author Contributions: Conceptualization, all authors; methodology, A.C.W. and H.M.; resources, all authors; writing-original draft preparation, A.C.W. and H.M.; writing-review and editing, A.C.W. and H.M.; funding acquisition, all authors. All authors have read and agreed to the published version of the manuscript.

Funding: This research was funded by NASA Research Opportunities in Space and Earth Science (ROSES) Grant \# NNX15AI48G, National Science Foundation Grants \# AGS-1544425 and \# AGS-1464501, Department of Defense Strategic Environmental Research and Development Program (SERDP) Grant \# RC20-C3-1025, USDA Forest Service Grant \# 19-CS-11261987-063, and US Joint Fire Science Program Grant \# 20-JV-11261987-005. Research reported in this paper was supported by the National Institute of Environmental Health Sciences of the National Institutes of Health under award number R01ES029528. The content is solely the responsibility of the authors and does not necessarily represent the official views of the National Institutes of Health.

Acknowledgments: The authors wish to thank our colleague Andrey Khlystov for discussions that helped shape the development of this manuscript, and the anonymous reviewers for their helpful comments.

Conflicts of Interest: The authors declare no conflict of interest. The funders had no role in the design of the study; in the collection, analyses, or interpretation of data; in the writing of the manuscript; or in the decision to publish the results.

\section{References}

1. NWCG Incident Operations Standards Working Team. Glossary of Wildland Fire Terminology; National Wildfire Coordinating Group (NWCG), National Interagency Fire Center, National Fire Equipment System: Boise, ID, USA, 2006; p. 183.

2. Bowman, D.M.J.S.; Balch, J.K.; Artaxo, P.; Bond, W.J.; Carlson, J.M.; Cochrane, M.A.; D'Antonio, C.M.; DeFries, R.S.; Doyle, J.C.; Harrison, S.P.; et al. Fire in the Earth System. Science 2009, 324, 481-484. [CrossRef] [PubMed]

3. Rothermel, R.C. A Mathematical Model for Predicting Fire Spread in Wildland Fuels; USDA Forest Service, Intermountain Experiment Station: Ogden, UT, USA, 1972; p. 46. 
4. Mell, W.E.; McDermott, R.J.; Forney, G.P. Wildland Fire Behavior Modeling: Perspectives, New Approaches and Applications. In Proceedings of the 3rd Fire Behavoir and Fuels Conference, Spokane, WA, USA, 25-29 October 2010.

5. Prichard, S.J.; Ottmar, R.D. State of Fire Behavior Models and their Application to Ecosystem and Smoke Management Issues: Special Session Summary Report. In Proceedings of the Smoke Symposium, International Association of Wildland Fire, College Park, MD, USA, 24 October 2013; p. 56.

6. Finney, M.A.; Cohen, J.D.; Forthofer, J.M.; McAllister, S.S.; Gollner, M.J.; Gorham, D.J.; Saito, K.; Akafuah, N.K.; Adam, B.A.; English, J.D. Role of Buoyant Flame Dynamics in Wildfire Spread. Proc. Natl. Acad. Sci. USA 2015, 112, 9833-9838. [CrossRef] [PubMed]

7. Albini, F.A. Estimating Wildfire Behavior and Effects; Intermountain Forest and Range Experimental Station, Forest Service, Department of Agriculture: Ogden, UT, USA, 1976; Volume 30, p. 92.

8. Scott, J.H.; Burgan, R.E. Standard Fire Behavior Fuel Models: A Comprehensive Set for Use with Rothermel's Surface Fire Spread Model; General Technical Report RMRS-GTR-153; USDA Forest Service, Rocky Mountain Research Station: Fort Collins, CO, USA, 2005; p. 172.

9. Ottmar, R.D.; Sandberg, D.V.; Riccardi, C.L.; Prichard, S.J. An Overview of the Fuel Characteristic Classification System-Quantifying, Classifying, and Creating Fuelbeds for Resource Planning. Can. J. For. Res. 2007, 37, 2383-2393. [CrossRef]

10. Weise, D.R.; Wright, C.S. Wildland Fire Emissions, Carbon and Climate: Characterizing Wildland Fuels. For. Ecol. Manag. 2014, 317, 26-40. [CrossRef]

11. Kochanski, A.; Fournier, A.; Mandel, J. Experimental Design of a Prescribed Burn Instrumentation. Atmosphere 2018, 9, 296. [CrossRef]

12. Liu, Y.; Kochanski, A.; Baker, K.R.; Mell, W.; Linn, R.; Paugam, R.; Mandel, J.; Fournier, A.; Jenkins, M.A.; Goodrick, S.; et al. Fire Behaviour and Smoke Modelling: Model Improvement and Measurement Needs for Next-Generation Smoke Research and Forecasting Systems. Int. J. Wildland Fire 2019, 28, 570-588. [CrossRef]

13. Prichard, S.; Larkin, S.N.; Ottmar, R.; French, H.N.; Baker, K.; Brown, T.; Clements, C.; Dickinson, M.; Hudak, A.; Kochanski, A.; et al. The Fire and Smoke Model Evaluation Experiment-A Plan for Integrated, Large Fire-Atmosphere Field Campaigns. Atmosphere 2019, 10, 66. [CrossRef]

14. Liu, Y.; Goodrick, S.; Achtemeier, G. The Weather Conditions for Desired Smoke Plumes at a FASMEE Burn Site. Atmosphere 2018, 9, 259. [CrossRef]

15. Mehadi, A.; Moosmüller, H.; Campbell, D.E.; Ham, W.; Schweizer, D.; Tarnay, L.; Hunter, J. Laboratory and Field Evaluation of Real-time and Near Real-time $\mathrm{PM}_{2.5}$ Smoke Monitors. J. Air Waste Manag. Assoc. 2020, 70, 158-179. [CrossRef]

16. Nelson, K.N.; Boehmler, J.M.; Khlystov, A.Y.; Moosmüller, H.; Samburova, V.; Bhattarai, C.; Wilcox, E.M.; Watts, A.C. A Smoke Emissions Sensing and Sampling Instrument Package for Small Unmanned Aircraft Systems: Development and Testing. Fire 2019, 2, 32. [CrossRef]

17. Engling, G.; Carrico, C.M.; Kreidenweis, S.M.; Collett, J.L., Jr.; Day, D.E.; Malm, W.C.; Lincoln, E.; Hao, W.M.; Iinuma, Y.; Herrmann, H. Determination of Levoglucosan in Biomass Combustion Aerosol by High Performance Anion Exchange Chromatography with Pulsed Amperometric Detection. Atmos. Environ. 2006, 40, S299-S311. [CrossRef]

18. Bytnerowicz, A.; Arbaugh, M.; Riebau, A.; Andersen, C. Wildland Fires and Air Pollution; Elsevier: Amsterdam, The Netherland, 2009; Volume 8.

19. Liu, J.C.; Pereira, G.; Uhl, S.A.; Bravo, M.A.; Bell, M.L. A Systematic Review of the Physical Health Impacts from Non-Occupational Exposure to Wildfire Smoke. Environ. Res. 2015, 136, 120-132. [CrossRef] [PubMed]

20. Johnston, F.H.; Henderson, S.B.; Chen, Y.; Randerson, J.T.; Marlier, M.; DeFries, R.S.; Kinney, P.; Bowman, D.M.J.S.; Brauer, M. Estimated Global Mortality Attributable to Smoke from Landscape Fires. Environ. Health Perspect. 2012, 120, 695-701. [CrossRef] [PubMed]

21. Ford, B.; Val Martin, M.; Zelasky, S.E.; Fischer, E.V.; Anenberg, S.C.; Heald, C.L.; Pierce, J.R. Future Fire Impacts on Smoke Concentrations, Visibility, and Health in the Contiguous United States. GeoHealth 2018, 2, 229-247. [CrossRef]

22. Ottmar, R.D. Wildland Fire Emissions, Carbon, and Climate: Modeling Fuel Consumption. For. Ecol. Manag. 2014, 317, 41-50. [CrossRef] 
23. O'Halloran, T.L.; Law, B.E.; Goulden, M.L.; Wang, Z.S.; Barr, J.G.; Schaaf, C.; Brown, M.; Fuentes, J.D.; Gockede, M.; Black, A.; et al. Radiative Forcing of Natural Forest Disturbances. Glob. Chang. Biol. 2012, 18, 555-565. [CrossRef]

24. Randerson, J.T.; Liu, H.; Flanner, M.G.; Chambers, S.D.; Jin, Y.; Hess, P.G.; Pfister, G.; Mack, M.C.; Treseder, K.K.; Welp, L.R.; et al. The Impact of Boreal Forest Fire on Climate Warming. Science 2006, 314, 1130. [CrossRef]

25. Westerling, A.L.; Gershunov, A.; Brown, T.J.; Cayan, D.R.; Dettinger, M.D. Climate and Wildfire in the Western United States. Bull. Am. Meteorol. Soc. 2003, 84, 595-604. [CrossRef]

26. Westerling, A.L.; Hidalgo, H.G.; Cayan, D.R.; Swetnam, T.W. Warming and Earlier Spring Increase Western US Forest Wildfire Activity. Science 2006, 313, 940-943. [CrossRef]

27. Akagi, S.K.; Yokelson, R.J.; Wiedinmyer, C.; Alvarado, M.J.; Reid, J.S.; Karl, T.; Crounse, J.D.; Wennberg, P.O. Emission Factors for Open and Domestic Biomass Burning for Use in Atmospheric Models. Atmos. Chem. Phys. 2011, 11, 4039-4072. [CrossRef]

28. French, N.H.F.; McKenzie, D.; Erickson, T.; Koziol, B.; Billmire, M.; Endsley, K.A.; Yager Scheinerman, N.K.; Jenkins, L.; Miller, M.E.; Ottmar, R.; et al. Modeling Regional-Scale Wildland Fire Emissions with the Wildland Fire Emissions Information System. Earth Interact. 2014, 18, 1-26. [CrossRef]

29. Watson, J.G.; Cao, J.; Chen, L.W.A.; Wang, Q.; Tian, J.; Wang, X.; Gronstal, S.; Ho, S.S.H.; Watts, A.C.; Chow, J.C. Gaseous, $\mathrm{PM}_{2.5}$ Mass, and Speciated Emission Factors from Laboratory Chamber Peat Combustion. Atmos. Chem. Phys. 2019, 19, 14173-14193. [CrossRef]

30. McMeeking, G.R.; Kreidenweis, S.M.; Baker, S.; Carrico, C.M.; Chow, J.C.; Collett, J.L., Jr.; Hao, W.M.; Holden, A.S.; Kirchstetter, T.W.; Malm, W.C.; et al. Emissions of Trace Gases and Aerosols during the Open Combustion of Biomass in the Laboratory. J. Geophys. Res. 2009, 114. [CrossRef]

31. Chen, L.-W.A.; Moosmüller, H.; Arnott, W.P.; Chow, J.C.; Watson, J.G.; Susott, R.A.; Babbitt, R.E.; Wold, C.E.; Lincoln, E.N.; Hao, W.M. Emissions from Laboratory Combustion of Wildland Fuels: Emission Factors and Source Profiles. Environ. Sci. Technol. 2007, 41, 4317-4325. [CrossRef]

32. Wiedinmyer, C.; Quayle, B.; Geron, C.; Belote, A.; McKenzie, D.; Zhang, X.Y.; O'Neill, S.; Wynne, K.K. Estimating Emissions from Fires in North America for Air Quality Modeling. Atmos. Environ. 2006, 40, 3419-3432. [CrossRef]

33. Conard, S.G.; Ivanova, G.A. Wildfire in Russian Boreal Forests-Potential Impacts of Fire Regime Characteristics on Emissions and Global Carbon Balance Estimates. Environ. Pollut. 1997, 98, 305-313. [CrossRef]

34. Conard, S.G.; Sukhinin, A.I.; Stocks, B.J.; Cahoon, D.R.; Davidenko, E.P.; Ivanova, G.A. Determining Effects of Area Burned and Fire Severity on Carbon Cycling and Emissions in Siberia. Clim. Chang. 2002, 55, 197-211. [CrossRef]

35. Schoennagel, T.; Balch, J.K.; Brenkert-Smith, H.; Dennison, P.E.; Harvey, B.J.; Krawchuk, M.A.; Mietkiewicz, N.; Morgan, P.; Moritz, M.A.; Rasker, R.; et al. Adapt to more wildfire in western North. American forests as climate changes. Proc. Natl. Acad. Sci. USA 2017, 114, 4582-4590. [CrossRef]

36. Ward, D.E. Factors Influencing the Emissions of Gases and Particulate Matter from Biomass Burning. In Fire in the Tropical Biota; Goldammer, J.G., Ed.; Springer: Berlin/Heidelberg, Germany, 1990; Volume 84, pp. 418-436.

37. Goodrick, S.L.; Brown, T.J.; Jolly, W.M. Weather, Fuels, Fire Behavior, Plumes, and Smoke-The Nexus of Fire Meteorology. Fire Manag. Today 2017, 75, 33-38.

38. Kim, Y.H.; King, C.; Krantz, T.; Hargrove, M.M.; George, I.J.; McGee, J.; Copeland, L.; Hays, M.D.; Landis, M.S.; Higuchi, M.; et al. The Role of Fuel Type and Combustion Phase on the Toxicity of Biomass Smoke Following Inhalation Exposure in Mice. Arch. Toxicol. 2019, 93, 1501-1513. [CrossRef]

39. Kim, Y.H.; Warren, S.H.; Krantz, Q.T.; King, C.; Jaskot, R.; Preston, W.T.; George, B.J.; Hays, M.D.; Landis, M.S.; Higuchi, M.; et al. Mutagenicity and Lung Toxicity of Smoldering vs. Flaming Emissions from Various Biomass Fuels: Implications for Health Effects from Wildland Fires. Environ. Health Perspect. 2018, 126, 017011. [CrossRef] [PubMed]

40. Watts, A.C.; Kobziar, L.N. Smoldering Combustion and Ground Fires: Ecological Effects and Multi-Scale Significance. Fire Ecol. 2013, 9, 124-132. [CrossRef]

41. Ferek, R.J.; Reid, J.S.; Hobbs, P.V.; Blake, D.R.; Liousse, C. Emission Factors of Hydrocarbons, Halocarbons, Trace gases and Particles from Biomass Burning in Brazil. J. Geophys. Res. 1998, 103, 32107-32118. [CrossRef] 
42. Hallquist, M.; Wenger, J.C.; Baltensperger, U.; Rudich, Y.; Simpson, D.; Claeys, M.; Dommen, J.; Donahue, N.M.; George, C.; Goldstein, A.H.; et al. The Formation, Properties, and Impact of Secondary Organic Aerosol: Current and Emerging Issues. Atmos. Chem. Phys. Discuss. 2009, 9, 3555-3762. [CrossRef]

43. Rudich, Y.; Donahue, N.M.; Mentel, T.F. Aging of Organic Aaerosol: Bridging the Gap Between Laboratory and Field Studies. Annu. Rev. Phys. Chem. 2007, 58, 321-352. [CrossRef] [PubMed]

44. Abbatt, J.P.D.; Lee, A.K.Y.; Thornton, J.A. Quantifying Trace Gas Uptake to Tropospheric Aerosol: Recent Advances and Remaining Challenges. Chem. Soc. Rev. 2012, 41, 6555-6581. [CrossRef]

45. Chakrabarty, R.K.; Moosmüller, H.; Garro, M.A.; Arnott, W.P.; Walker, J.W.; Susott, R.A.; Babbitt, R.E.; Wold, C.E.; Lincoln, E.N.; Hao, W.M. Emissions from the Laboratory Combustion of Wildland Fuels: Particle Morphology and Size. J. Geophys. Res. 2006, 111. [CrossRef]

46. Chen, L.W.A.; Verburg, P.; Shackelford, A.; Zhu, D.; Susfalk, R.; Chow, J.C.; Watson, J.G. Moisture Effects on Carbon and Nitrogen Emission from Burning of Wildland Biomass. Atmos. Chem. Phys. 2010, 10, 6617-6625. [CrossRef]

47. Menning, K.M.; Stephens, S.L. Fire Climbing in the Forest: A Semiqualitative, Semiquantitative Approach to Assessing Ladder Fuel Hazards. West. J. Appl. For. 2007, 22, 88-93. [CrossRef]

48. Benavent-Corai, J.; Rojo, C.; Suárez-Torres, J.; Velasco-García, L. Scaling Properties in Forest Fire Sequences: The Human Role in the Order of Nature. Ecol. Model. 2007, 205, 336-342. [CrossRef]

49. Porterie, B.; Kaiss, A.; Clerc, J.-P.; Zekri, L.; Zekri, N. Universal Scaling In Wildfire Fractal Propagation. Appl. Phys. Lett. 2008, 93, 204101. [CrossRef]

50. Ichoku, C.; Kaufman, Y.J. A Method to Derive Smoke Emission Rates from MODIS Fire Radiative Energy Measurements. IEEE Trans. Geosci. Remote Sens. 2005, 43, 2636-2649. [CrossRef]

51. Randerson, J.T.; Chen, Y.; van der Werf, G.R.; Rogers, B.M.; Morton, D.C. Global Burned Area and Biomass Burning Emissions from Small Fires. J. Geophys. Res. 2012, 117. [CrossRef]

52. Van der Werf, G.R.; Randerson, J.T.; Giglio, L.; Collatz, G.J.; Mu, M.; Kasibhatla, P.S.; Morton, D.C.; DeFries, R.S.; Jin, Y.; van Leeuwen, T.T. Global Fire Emissions and the Contribution of Deforestation, Savanna, Forest, Agricultural, and Peat Fires (1997-2009). Atmos. Chem. Phys. 2010, 10, 11707-11735. [CrossRef]

53. Giglio, L.; Randerson, J.T.; van der Werf, G.R. Analysis of Daily, Monthly, and Annual Burned Area Using the Fourth-Generation Global Fire Emissions Database (GFED4). J. Geophys. Res. 2013, 118, 317-328. [CrossRef]

54. Congalton, G.R.; Gu, J.; Yadav, K.; Thenkabail, P.; Ozdogan, M. Global Land Cover Mapping: A Review and Uncertainty Analysis. Remote Sens. 2014, 6, 12070-12093. [CrossRef]

55. Page, S.E.; Siegert, F.; Rieley, J.O.; Boehm, H.-D.V.; Jaya, A.; Limin, S. The Amount of Carbon Released from Peat and Forest Fires in Indonesia during 1997. Nature 2002, 420, 61-65. [CrossRef]

56. French, N.H.F.; de Groot, W.J.; Jenkins, L.K.; Rogers, B.M.; Alvarado, E.; Amiro, B.; de Jong, B.; Goetz, S.; Hoy, E.; Hyer, E.; et al. Model Comparisons for Estimating Carbon Emissions from North American Wildland Fire. J. Geophys. Res. 2011, 116. [CrossRef]

57. Schultz, M.G.; Heil, A.; Hoelzemann, J.J.; Spessa, A.; Thonicke, K.; Goldammer, J.G.; Held, A.C.; Pereira, J.M.C.; van het Bolscher, M. Global Wildland Fire Emissions from 1960 to 2000. Glob. Biogeochem. Cycles 2008, 22. [CrossRef]

58. Andreae, M.O. Emission of Trace Gases and Aerosols from Biomass Burning-An Updated Assessment. Atmos. Chem. Phys. 2019, 19, 8523-8546. [CrossRef]

59. Duclos, P.; Sanderson, L.M.; Lipsett, M. The 1987 Forest Fire Disaster in California: Assessment of Emergency Room Visits. Arch. Environ. Health 1990, 45, 53-58. [CrossRef] [PubMed]

60. Künzli, N.; Avol, E.; Wu, J.; Gauderman, W.J.; Rappaport, E.; Millstein, J.; Bennion, J.; McConnell, R.; Gilliland, F.D.; Berhane, K.; et al. Health Effects of the 2003 Southern California Wildfires on Children. Am. J. Respir. Crit. Care Med. 2006, 174, 1221-1228. [CrossRef] [PubMed]

61. Doerr, S.H.; Santín, C. Global Trends in Wildfire and its Impacts: Perceptions versus Realities in a Changing World. Phil. Trans. R. Soc. B 2016, 371, 20150345. [CrossRef] [PubMed]

62. Kim, M.-K.; Jakus, P.M. Wildfire, National Park Visitation, and Changes in Regional Economic Activity. J. Outdoor Recreat. Tour. 2019, 26, 34-42. [CrossRef]

63. Kochi, I.; Champ, P.A.; Loomis, J.B.; Donovan, G.H. Valuing Morbidity Effects of Wildfire Smoke Exposure from the 2007 Southern California Wildfires. J. For. Econ. 2016, 25, 29-54. [CrossRef] 
64. Laursen, K.K.; Hobbs, P.V.; Radke, L.F.; Rasmussen, R.A. Some Trace Gas Emissions from North American Biomass Fires with an Assessment of Regional and Global Fluxes from Biomass Burning. J. Geophys. Res. 1992, 97, 20687-20701. [CrossRef]

65. Zhang, Y.; Forrister, H.; Liu, J.; Dibb, J.; Anderson, B.; Schwarz, J.P.; Perring, A.E.; Jimenez, J.L.; Campuzano-Jost, P.; Wang, Y.; et al. Top-of-Atmosphere Radiative Forcing Affected by Brown Carbon in the Upper Troposphere. Nat. Geosci. 2017, 10, 486-489. [CrossRef]

66. Giglio, L.; Loboda, T.; Roy, D.P.; Quayle, B.; Justice, C.O. An Active-Fire Based Burned Area Mapping Algorithm for the MODIS Sensor. Remote Sens. Environ. 2009, 113, 408-420. [CrossRef]

67. Simon, M.; Plummer, S.; Fierens, F.; Hoelzemann, J.J.; Arino, O. Burnt Area Detection at Global Scale Using ATSR-2: The GLOBSCAR Products and their Qualification. J. Geophys. Res. 2004, 109. [CrossRef]

68. Hoelzemann, J.J.; Schultz, M.G.; Brasseur, G.P.; Granier, C.; Simon, M. Global Wildland Fire Emission Model (GWEM): Evaluating the Use of Global Area Burnt Satellite Data. J. Geophys. Res. 2004, 109. [CrossRef]

69. Brown, T.; Clements, C.; Larkin, N.; Anderson, K.; Butler, B.; Goodrick, S.; Ichoku, C.; Lamb, B.; Mell, R.; Ottmar, R. Validating the Next Generation of Wildland Fire and Smoke Models for Operational and Research Use-A National Plan; Joint Fire Science Program: Boise, ID, USA, 2014; p. 73.

70. Garofalo, L.; Pothier, M.A.; Levin, E.J.T.; Campos, T.; Kreidenweis, S.M.; Farmer, D.K. Emission and Evolution of Submicron Organic Aerosol in Smoke from Wildfires in the Western United States. ACS Earth Space Chem. 2019. [CrossRef]

71. Warneke, C.; Schwarz, J.P.; Ryerson, T.; Crawford, J.; Dibb, J.; Lefer, B.; Roberts, J.; Trainer, M.; Murphy, D.; Brown, S.; et al. Fire Influence on Regional to Global Environments and Air Quality (FIREX-AQ): A NOAA/NASA Interagency Intensive Study of North American Fires: 2018; National Oceanic and Atmospheric Administration: Boulder, CO, USA, 2018. Available online: https://www.esrl.noaa.gov/csd/projects/firex/whitepaper.pdf (accessed on 14 June 2020).

72. Prosser, I.P.; Williams, L. The Effect of Wildfire on Runoff and Erosion in Native Eucalyptus Forest. Hydrol. Process. 1998, 12, 251-265. [CrossRef]

73. Miller, J.D.; Safford, H. Trends in Wildfire Severity: 1984 to 2010 in the Sierra Nevada, Modoc Plateau, and Southern Cascades, California, USA. Fire Ecol. 2012, 8, 41-57. [CrossRef]

74. Baker, W.L. Are High-Severity Fires Burning at Much Higher Rates Recently than Historically in Dry-Forest Landscapes of the Western USA? PLoS ONE 2015, 10, e0136147. [CrossRef]

75. Baker, W.L. Correction: Are High-Severity Fires Burning at Much Higher Rates Recently than Historically in Dry-Forest Landscapes of the Western USA? PLoS ONE 2015, 10, e0141936. [CrossRef] [PubMed]

76. Abatzoglou, J.T.; Williams, A.P. Impact of Anthropogenic Climate Change on Wildfire across Western US Forests. Proc. Natl. Acad. Sci. USA 2016, 113, 11770-11775. [CrossRef] [PubMed]

77. Brown, T.J.; Hall, B.L.; Westerling, A.L. The Impact of Twenty-First Century Climate Change on Wildland Fire Danger in the Western United States: An Applications Perspective. Clim. Chang. 2004, 62, 365-388. [CrossRef]

78. Liu, Y.; Stanturf, J.; Goodrick, S. Trends in Global Wildfire Potential in a Changing Climate. For. Ecol. Manag. 2010, 259, 685-697. [CrossRef]

79. Moritz, M.A.; Parisien, M.-A.; Batllori, E.; Krawchuk, M.A.; Van Dorn, J.; Ganz, D.J.; Hayhoe, K. Climate Change and Disruptions to Global Fire Activity. Ecosphere 2012, 3, art49. [CrossRef]

80. Knorr, W.; Dentener, F.; Lamarque, J.F.; Jiang, L.; Arneth, A. Wildfire Air Pollution Hazard during the 21st Century. Atmos. Chem. Phys. 2017, 17, 9223-9236. [CrossRef]

81. Knorr, W.; Jiang, L.; Arneth, A. Climate, $\mathrm{CO}_{2}$ and Human Population Impacts on Global Wildfire Emissions. Biogeosciences 2016, 13, 267-282. [CrossRef]

82. Andela, N.; Morton, D.C.; Giglio, L.; Paugam, R.; Chen, Y.; Hantson, S.; Van Der Werf, G.R.; Randerson, J.T. The Global Fire Atlas of Individual Fire Size, Duration, Speed and Direction. Earth Syst. Sci. Data 2019, 11, 529-552. [CrossRef]

83. Christian, T.J.; Kleiss, B.; Yokelson, R.J.; Holzinger, R.; Crutzen, P.J.; Hao, W.M.; Saharjo, B.H.; Ward, D.E. Comprehensive Laboratory Measurements of Biomass-Burning Emissions: 1 Emissions from Indonesian, African, and Other Fuels. J. Geophys. Res. 2003, 108. [CrossRef]

84. Cofer, W.R., III; Levine, J.S.; Sebacher, D.I.; Winstead, E.L.; Riggan, P.J.; Stocks, B.J.; Brass, J.A.; Ambrosia, V.G.; Boston, P.J. Trace Gas Emissions from Chaparral and Boreal Forest Fires. J. Geophys. Res. 1989, 94, $2255-2259$. [CrossRef] 
85. Cofer, W.R., III; Levine, J.S.; Winstead, E.L.; Stocks, B.J. Gaseous Emissions from Canadian Boreal Forest Fires. Atmos. Environ. 1990, 24, 1653-1659. [CrossRef]

86. Keene, W.C.; Lobert, R.M.; Crutzen, P.J.; Maben, J.R.; Scharffe, D.H.; Landmann, T.; Hély, C.; Brain, C. Emissions of Major Gaseous and Particulate Species during Experimental Burns of Southern African Biomass. J. Geophys. Res. 2006, 111. [CrossRef]

87. Lacaux, J.P.; Cachier, H.; Delmas, R. Biomass Burning in Africa: An Overview of its Impact on Atmospheric Chemistry. In Fire in the Environment: The Ecological, Atmospheric, and Climatic Importance of Vegetation Fires; Crutzen, P.J., Goldammer, J.G., Eds.; John Wiley: New York, NY, USA, 1993; pp. 159-191.

88. May, A.A.; McMeeking, G.R.; Lee, T.; Taylor, J.W.; Craven, J.S.; Burling, I.; Sullivan, A.P.; Akagi, S.; Collett, J.L., Jr.; Flynn, M.; et al. Aerosol Emissions from Prescribed Fires in the United States: A Synthesis of Laboratory and Aircraft Measurements. J. Geophys. Res. 2014, 119, 11826-11849. [CrossRef]

89. Nara, H.; Tanimoto, H.; Tohjima, Y.; Mukai, H.; Nojiri, Y.; Machida, T. Emission factors of $\mathrm{CO}_{2}, \mathrm{CO}_{\text {and }} \mathrm{CH}_{4}$ from Sumatran peatland fires in 2013 based on shipboard measurements. Tellus B Chem. Phys. Meteorol. 2017, 69, 1399047. [CrossRef]

90. Radke, L.F.; Hegg, D.A.; Hobbs, P.V.; Nance, J.D.; Lyons, J.H.; Laursen, K.K.; Weiss, R.E.; Riggan, P.J.; Ward, D.E. Particulate and Trace Gas Emissions from Large Biomass Fires in North America. In Global Biomass Burning: Atmospheric, Climatic, and Biospheric Implications; Levine, J.S., Ed.; MIT Press: Cambridge, MA, USA, 1991; pp. 209-224.

91. Sinha, P.; Hobbs, P.V.; Yokelson, R.J.; Bertschi, I.T.; Blake, D.R.; Simpson, I.J.; Gao, S.; Kirchstetter, T.W.; Novakov, T. Emissions of Trace Gases and Particles from Savanna Fires in Southern Africa. J. Geophys. Res. 2003, 108. [CrossRef]

92. Sinha, P.; Hobbs, P.V.; Yokelson, R.J.; Blake, D.R.; Gao, S.; Kirchstetter, T.W. Emissions from Miombo Woodland and Dambo Grassland Savanna Fires. J. Geophys. Res. 2004, 109. [CrossRef]

93. Smith, T.E.L.; Evers, S.; Yule, C.M.; Gan, J.Y. In Situ Tropical Peatland Fire Emission Factors and Their Variability, as Determined by Field Measurements in Peninsula Malaysia. Glob. Biogeochem. Cycles 2018, 32, 18-31. [CrossRef]

94. Smith, T.E.L.; Paton-Walsh, C.; Meyer, C.P.; Cook, G.D.; Maier, S.W.; Russell-Smith, J.; Wooster, M.J.; Yates, C.P. New Emission Factors for Australian Vegetation Fires Measured Using Open-Path Fourier Transform Infrared Spectroscopy-Part 2: Australian Tropical Savanna Fires. Atmos. Chem. Phys. 2014, 14, 11335-11352. [CrossRef]

95. Soares Neto, T.G.; Carvalho, J.A.; Cortez, E.V.; Azevedo, R.G.; Oliveira, R.A.; Fidalgo, W.R.R.; Santos, J.C. Laboratory Evaluation of Amazon Forest Biomass Burning Emissions. Atmos. Environ. 2011, 45, 7455-7461. [CrossRef]

96. Soares Neto, T.G.; Carvalho, J.A.; Veras, C.A.G.; Alvarado, E.C.; Gielow, R.; Lincoln, E.N.; Christian, T.J.; Yokelson, R.J.; Santos, J.C. Biomass Consumption and $\mathrm{CO}_{2}, \mathrm{CO}$ and Main Hydrocarbon Gas Emissions in an Amazonian Forest Clearing Fire. Atmos. Environ. 2009, 43, 438-446. [CrossRef]

97. Stockwell, C.E.; Jayarathne, T.; Cochrane, M.A.; Ryan, K.C.; Putra, E.I.; Saharjo, B.H.; Nurhayati, A.D.; Albar, I.; Blake, D.R.; Simpson, I.J.; et al. Field Measurements of Trace Gases and Aerosols Emitted by Peat Fires in Central Kalimantan, Indonesia, during the 2015 El Niño. Atmos. Chem. Phys. 2016, 16, 11711-11732. [CrossRef]

98. Strand, T.; Gullett, B.; Urbanski, S.; O’Neill, S.; Potter, B.; Aurell, J.; Holder, A.; Larkin, N.; Moore, M.; Rorig, M. Grassland and Forest Understorey Biomass Emissions from Prescribed Fires in the South-Eastern United States-RxCADRE 2012. Int. J. Wildland Fire 2016, 25, 102-113. [CrossRef]

99. Yokelson, R.J.; Burling, I.R.; Gilman, J.B.; Warneke, C.; Stockwell, C.E.; de Gouw, J.; Akagi, S.K.; Urbanski, S.P.; Veres, P.; Roberts, J.M.; et al. Coupling Field and Laboratory Measurements to Estimate the Emission Factors of Identified and Unidentified Trace Gases for Prescribed Fires. Atmos. Chem. Phys. 2013, 13, 89-116. [CrossRef]

100. Andreae, M.O.; Merlet, P. Emission of Trace Gases and Aerosols from Biomass Burning. Glob. Biogeochem. Cycles 2001, 15, 955-966. [CrossRef]

101. Prichard, S.J.; Ottmar, R.D.; Anderson, G.K. Consume 3.0 User's Guide; Pacific Wildland Fire Sciences Laboratory, USDA Forest Service, Pacific Northwest Research Station: Seattle, WA, USA, 2006.

102. Olson, J.S.; Watts, J.A.; Allison, L.J. Carbon in Live Vegetation of Major World Ecosystems; ORNL-5862; Office of Energy Research, U.S. Department of Energy: Washington, DC, USA, 1983; p. 181. 
103. Gibbs, H.K. Olson's Major World Ecosystem Complexes Ranked by Carbon in Live Vegetation: An Updated Database Using the GLC2000 Land Cover Product NDP-017b; Oak Ridge National Laboratory: Oak Ridge, TN, USA, 2006.

104. Kasischke, E.S.; French, N.H.F.; Harrell, P.; Christensen, N.L., Jr.; Ustin, S.L.; Barry, D. Monitoring of Wildfires in Boreal Forests Using Large-Area AVHRR NDVI Composite Image Data. Remote Sens. Environ. 1993, 45, 61-71. [CrossRef]

105. Kasischke, E.S.; Hyer, E.J.; Novelli, P.C.; Bruhwiler, L.P.; French, N.H.F.; Sukhinin, A.I.; Hewson, J.H.; Stocks, B.J. Influences of Boreal Fire Emissions on Northern Hemisphere Atmospheric Carbon and Carbon Monoxide. Glob. Biogeochem. Cycles 2005, 19. [CrossRef]

106. Hao, W.M.; Ward, D.E.; Olbu, G.; Baker, S.P. Emissions of $\mathrm{CO}_{2}, \mathrm{CO}$, and hydrocarbons from fires in diverse African savanna ecosystems. J. Geophys. Res. 1996, 101, 23577-23584. [CrossRef]

107. Bian, Q.; Jathar, S.H.; Kodros, J.K.; Barsanti, K.C.; Hatch, L.E.; May, A.A.; Kreidenweis, S.M.; Pierce, J.R. Secondary Organic Aerosol Formation in Biomass-Burning Plumes: Theoretical Analysis of Lab Studies and Ambient Plumes. Atmos. Chem. Phys. 2017, 17, 5459-5475. [CrossRef]

108. Jaffe, D.A.; Wigder, N.L. Ozone Production from Wildfires: A Critical Review. Atmos. Environ. 2012, 51, 1-10. [CrossRef]

109. Jaffe, D.A.; O’Neill, S.M.; Larkin, N.K.; Holder, A.L.; Peterson, D.L.; Halofsky, J.E.; Rappold, A.G. Wildfire and Prescribed Burning Impacts on Air Quality in the United States. J. Air Waste Manag. Assoc. 2020. [CrossRef]

110. Oliveira, M.; Delerue-Matos, C.; Pereira, M.C.; Morais, S. Environmental Particulate Matter Levels during 2017 Large Forest Fires and Megafires in the Center Region of Portugal: A Public Health Concern? Int. J. Environ. Res. Public Health 2020, 17, 1032. [CrossRef] [PubMed]

111. Williamson, G.J.; Prior, L.D.; Jolly, W.M.; Cochrane, M.A.; Murphy, B.P.; Bowman, D.M.J.S. Measurement of Inter- and Intra-Annual Variability of Landscape Fire Activity at a Continental Scale: The Australian Case. Environ. Res. Lett. 2016, 11, 035003. [CrossRef]

112. See, S.W.; Balasubramanian, R.; Rianawati, E.; Karthikeyan, S.; Streets, D.G. Characterization and Source Apportionment of Particulate Matter $\leq 2.5 \mu \mathrm{m}$ in Sumatra, Indonesia, during a Recent Peat Fire Episode. Environ. Sci. Technol. 2007, 41, 3488-3494. [CrossRef]

113. Cui, M.; Chen, Y.; Zheng, M.; Li, J.; Tang, J.; Han, Y.; Song, D.; Yan, C.; Zhang, F.; Tian, C.; et al. Emissions and Characteristics of Particulate Matter from Rainforest Burning in the Southeast Asia. Atmos. Environ. 2018, 191, 194-204. [CrossRef]

114. Engling, G.; He, J.; Betha, R.; Balasubramanian, R. Assessing the Regional Impact of Indonesian Biomass Burning Emissions Based on Organic Molecular Tracers and Chemical Mass Balance Modeling. Atmos. Chem. Phys. 2014, 14, 8043-8054. [CrossRef]

115. Betha, R.; Behera, S.N.; Balasubramanian, R. 2013 Southeast Asian Smoke Haze: Fractionation of Particulate-Bound Elements and Associated Health Risk. Environ. Sci. Technol. 2014, 48, 4327-4335. [CrossRef]

116. Heil, A.; Langmann, B.; Aldrian, E. Indonesian Peat and Vegetation Fire Emissions: Study on Factors Influencing Large-Scale Smoke Haze Pollution Using a Regional Atmospheric Chemistry Model. Mitig. Adapt. Strateg. Glob. Chang. 2007, 12, 113-133. [CrossRef]

117. Sastry, N. Forest Fires, Air Pollution, and Mortality in Southeast Asia. Demography 2002, 39, 1-23. [CrossRef] [PubMed]

118. Campbell, J.; Donato, D.; Azuma, D.; Law, B. Pyrogenic Carbon Emission from a Large Wildfire in Oregon, United States. J. Geophys. Res. 2007, 112. [CrossRef]

119. Hosseini, S.; Urbanski, S.P.; Dixit, P.; Qi, L.; Burling, I.R.; Yokelson, R.J.; Johnson, T.J.; Shrivastava, M.; Jung, H.S.; Weise, D.R.; et al. Laboratory Characterization of PM Emissions from Combustion of Wildland Biomass Fuels. J. Geophys. Res. 2013, 118, 9914-9929. [CrossRef]

120. Urbanski, S. Wildland Fire Emissions, Carbon, and Climate: Emission Factors. For. Ecol. Manag. 2014, 317, 51-60. [CrossRef]

121. Aurell, J.; Gullett, B.K.; Tabor, D. Emissions from Southeastern U.S. Grasslands and Pine Savannas: Comparison of Aerial and Ground Field Measurements with Laboratory Burns. Atmos. Environ. 2015, 111, 170-178. [CrossRef]

122. Chakrabarty, R.K.; Moosmüller, H.; Chen, L.-W.A.; Lewis, K.; Arnott, W.P.; Mazzoleni, C.; Dubey, M.K.; Wold, C.E.; Hao, W.M.; Kreidenweis, S.M. Brown Carbon in Tar Balls from Smoldering Biomass Combustion. Atmos. Chem. Phys. 2010, 10, 6363-6370. [CrossRef] 
123. Chen, L.-W.A.; Moosmüller, H.; Arnott, W.P.; Chow, J.C.; Watson, J.G.; Susott, R.A.; Babbitt, R.E.; Wold, C.E.; Lincoln, E.N.; Hao, W.M. Particle Emissions from Laboratory Combustion of Wildland Fuels: In Situ Optical and Mass Measurements. Geophys. Res. Lett. 2006, 33. [CrossRef]

124. Cheng, Y.; Engling, G.; Moosmüller, H.; Arnott, W.P.; Chen, A.L.W.; Wold, C.E.; Hao, W.M.; He, K.B. Light Absorption by Biomass Burning Source Emissions. Atmos. Environ. 2016, 127, 347-354. [CrossRef]

125. DeMott, P.J.; Petters, M.D.; Prenni, A.J.; Carrico, C.M.; Kreidenweis, S.M.; Collett, J.L.; Moosmüller, H. Ice Nucleation Behavior of Biomass Combustion Particles at Cirrus Temperatures. J. Geophys. Res. 2009, 114. [CrossRef]

126. Levin, E.J.T.; McMeeking, G.R.; Carrico, C.M.; Mack, L.E.; Kreidenweis, S.M.; Wold, C.E.; Moosmüller, H.; Arnott, W.P.; Hao, W.M.; Collett, J.; et al. Biomass Burning Smoke Aerosol Properties Measured during FLAME. J. Geophys. Res. 2010, 115. [CrossRef]

127. Lewis, K.; Arnott, W.P.; Moosmüller, H.; Chakrabarty, R.K.; Carrico, C.M.; Kreidenweis, S.M.; Day, D.E.; Malm, W.C.; Laskin, A.; Jimenez, J.L.; et al. Reduction in Biomass Burning Aerosol Light Absorption upon Humidification: Roles of Inorganically-Induced Hygroscopicity, Particle Collapse, and Photoacoustic Heat and Mass Transfer. Atmos. Chem. Phys. 2009, 9, 8949-8966. [CrossRef]

128. Lewis, K.; Arnott, W.P.; Moosmüller, H.; Wold, C.E. Strong Spectral Variation of Biomass Smoke Light Absorption and Single Scattering Albedo Observed with a Novel Dual-Wavelength Photoacoustic Instrument. J. Geophys. Res. 2008, 113. [CrossRef]

129. Mack, L.A.; Levin, E.J.T.; Kreidenweis, S.M.; Obrist, D.; Moosmüller, H.; Lewis, K.A.; Arnott, W.P.; McMeeking, G.R.; Sullivan, A.P.; Wold, C.E.; et al. Optical Closure Experiments for Biomass Smoke Aerosols. Atmos. Chem. Phys. 2010, 10, 9017-9026. [CrossRef]

130. Mazzoleni, L.R.; Zielinska, B.; Moosmüller, H. Emissions of Levoglucosan, Methoxy Phenols, and Organic Acids from Prescribed Burns, Laboratory Combustion of Wildland Fuels, and Residential Wood Combustion. Environ. Sci. Technol. 2007, 41, 2115-2122. [CrossRef]

131. Obrist, D.; Moosmuller, H.; Schurmann, R.; Chen, L.W.A.; Kreidenweis, S.M. Particulate-Phase and Gaseous Elemental Mercury Emissions during Biomass Combustion: Controlling Factors and Correlation with Particulate Matter Emissions. Environ. Sci. Technol. 2008, 42, 721-727. [CrossRef]

132. Petters, M.D.; Carrico, C.M.; Kreidenweis, S.M.; Prenni, A.J.; DeMott, P.J.; Collett, J.L.; Moosmüller, H. Cloud Condensation Nucleation Activity of Biomass Burning Aerosol. J. Geophys. Res. 2009, 114. [CrossRef]

133. Petters, M.D.; Parsons, M.T.; Prenni, A.J.; DeMott, P.J.; Kreidenweis, S.M.; Carrico, C.M.; Sullivan, A.P.; McMeeking, G.R.; Levin, E.; Wold, C.E.; et al. Ice Nuclei Emissions from Biomass Burning. J. Geophys. Res. 2009, 114. [CrossRef]

134. Watson, J.G.; Chow, J.C.; Chen, L.-W.A.; Lowenthal, D.H.; Fujita, E.M.; Kuhns, H.D.; Sodeman, D.A.; Campbell, D.E.; Moosmüller, H.; Zhu, D.; et al. Particulate Emission Factors for Mobile Fossil Fuel and Biomass Combustion Sources. Sci. Total Environ. 2011, 409, 2384-2396. [CrossRef] [PubMed]

135. Langmann, B.; Heil, A. Release and Dispersion of Vegetation and Peat Fire Emissions in the Atmosphere over Indonesia 1997/1998. Atmos. Chem. Phys. 2004, 4, 2145-2160. [CrossRef]

136. Bhattarai, C.; Samburova, V.; Sengupta, D.; Iaukea-Lum, M.; Watts, A.C.; Moosmüller, H.; Khlystov, A.Y. Physical and Chemical Characterization of Aerosol in Fresh and Aged Emissions from Open Combustion of Biomass Fuels. Aerosol Sci. Technol. 2018, 52, 1266-1282. [CrossRef]

137. Sengupta, D.; Samburova, V.; Bhattarai, C.; Kirillova, E.; Mazzoleni, L.; Iaukea-Lum, M.; Watts, A.; Moosmüller, H.; Khlystov, A. Light Absorption by Polar and Non-Polar Aerosol Compounds from Laboratory Biomass Combustion. Atmos. Chem. Phys. 2018, 18, 10849-10867. [CrossRef]

138. Yatavelli, R.L.N.; Chen, L.W.A.; Knue, J.; Samburova, V.; Gyawali, M.; Watts, A.C.; Chakrabarty, R.K.; Moosmüller, H.; Hodzic, A.; Wang, X.; et al. Emissions and Partitioning of Intermediate-Volatility and Semi-Volatile Polar Organic Compounds (I/SV-POCs) during Laboratory Combustion of Boreal and Sub-Tropical Peat. Aerosol Sci. Eng. 2017. [CrossRef]

139. Jayarathne, T.; Stockwell, C.E.; Gilbert, A.A.; Daugherty, K.; Cochrane, M.A.; Ryan, K.C.; Putra, E.I.; Saharjo, B.H.; Nurhayati, A.D.; Albar, I.; et al. Chemical Characterization of Fine Particulate Matter Emitted by Peat Fires in Central Kalimantan, Indonesia, during the 2015 El Niño. Atmos. Chem. Phys. 2018, 18, 2585-2600. [CrossRef]

140. Roulston, C.; Paton-Walsh, C.; Smith, T.E.L.; Guérette, É.A.; Evers, S.; Yule, C.M.; Rein, G.; Van der Werf, G.R. Fine Particle Emissions from Tropical Peat Fires Decrease Rapidly with Time Since Ignition. J. Geophys. Res. Atmos. 2018, 123, 5607-5617. [CrossRef] [PubMed] 
141. Chow, J.C.; Cao, J.; Antony Chen, L.W.; Wang, X.; Wang, Q.; Tian, J.; Ho, S.S.H.; Watts, A.C.; Carlson, T.B.; Kohl, S.D.; et al. Changes in $\mathrm{PM}_{2.5}$ Peat Combustion Source Profiles with Atmospheric Aging in an Oxidation Flow Reactor. Atmos. Meas. Tech. 2019, 12, 5475-5501. [CrossRef]

142. Sengupta, D.; Samburova, V.; Bhattarai, C.; Watts, A.C.; Moosmüller, H.; Khlystov, A.Y. Polar Fraction of Semi-Volatile Organic Compounds in Biomass Burning Emissions and their Chemical Transformations during Aging with an Oxidation Flow Reactor. Atmos. Chem. Phys. Discuss. 2020. [CrossRef]

143. Wieder, R.K.; Scott, K.D.; Kamminga, K.; Vile, M.A.; Vitt, D.H.; Bone, T.; Xu, B.I.N.; Benscoter, B.W.; Bhatti, J.S. Postfire Carbon Balance in Boreal Bogs of Alberta, Canada. Glob. Chang. Biol. 2009, 15, 63-81. [CrossRef]

144. Benscoter, B.W.; Thompson, D.K.; Waddington, J.M.; Flannigan, M.D.; Wotton, B.M.; de Groot, W.J.; Turetsky, M.R. Interactive Effects of Vegetation, Soil Moisture and Bulk Density on Depth of Burning of Thick Organic Soils. Int. J. Wildland Fire 2011, 20, 418-429. [CrossRef]

145. Watts, A.C.; Schmidt, C.A.; McLaughlin, D.L.; Kaplan, D.A. Hydrologic Implications of Smoldering Fires in Wetland Landscapes. Freshw. Sci. 2015, 34, 1394-1405. [CrossRef]

146. Hadden, R.M.; Rein, G.; Belcher, C.M. Study of the Competing Chemical Reactions in the Initiation and Spread of Smouldering Combustion in Peat. Proc. Combust. Inst. 2013, 34, 2547-2553. [CrossRef]

147. Rein, G. Smouldering Combustion Phenomena in Science and Technology. Int. Rev. Chem. Eng. 2009, 1, 3-18.

148. Prat-Guitart, N.; Rein, G.; Hadden, R.M.; Belcher, C.M.; Yearsley, J.M. Propagation Probability and Spread Rates of Self-Sustained Smouldering Fires under Controlled Moisture Content and Bulk Density Conditions. Int. J. Wildland Fire 2016, 25, 456-465. [CrossRef]

149. Huang, X.; Restuccia, F.; Gramola, M.; Rein, G. Experimental Study of the Formation and Collapse of an Overhang in the Lateral Spread of Smouldering Peat Fires. Combust. Flame 2016, 168, 393-402. [CrossRef]

150. Huang, X.; Rein, G. Downward Spread of Smouldering Peat Fire: The Role of Moisture, Density and Oxygen Supply. Int. J. Wildland Fire 2017, 26, 907-918. [CrossRef]

151. Hu, Y.; Christensen, E.; Restuccia, F.; Rein, G. Transient Gas and Particle Emissions from Smouldering Combustion of Peat. Proc. Combust. Inst. 2019, 37, 4035-4042. [CrossRef]

152. Stockwell, C.E. Advanced Measurements of Undersampled Globally Significant Biomass Burning Sources. Ph.D. Thesis, University of Montana, Missoula, MT, USA, 2016.

153. Cofer, W.R., III; Winstead, E.L.; Stocks, B.J.; Overbay, L.W.; Goldammer, J.G.; Cahoon, D.R.; Levine, J.S. Emissions from Boreal Forest Fires: Are the Atmospheric Impacts Underestimated. In Biomass Burning and Global Change; Levine, J.S., Ed.; MIT Press: Cambridge, MA, USA, 1996.

154. French, N.H.F.; Goovaerts, P.; Kasischke, E.S. Uncertainty in Estimating Carbon Emissions from Boreal Forest Fires. J. Geophys. Res. 2004, 109. [CrossRef]

155. Kreye, J.K.; Brewer, N.W.; Morgan, P.; Varner, J.M.; Smith, A.M.S.; Hoffman, C.M.; Ottmar, R.D. Fire Behavior in Masticated Fuels: A Review. For. Ecol. Manag. 2014, 314, 193-207. [CrossRef]

156. Knapp, E.E.; Varner, J.M.; Busse, M.D.; Skinner, C.N.; Shestak, C.J. Behaviour and Effects of Prescribed Fire in Masticated Fuelbeds. Int. J. Wildland Fire 2011, 20, 932-945. [CrossRef]

157. Kane, J.M.; Knapp, E.E.; Varner, J.M. Variability in Loading of Mechanically Masticated Fuel Beds in Northern California and Southwestern Oregon. In Proceedings of the Fuels Management-How to Measure Success, Portland, OR, USA, 28-30 March 2006; pp. 341-350.

158. Kreye, J.K.; Varner, J.M.; Knapp, E.E. Effects of Particle Fracturing and Moisture Content on Fire Behaviour in Masticated Fuelbeds Burned in a Laboratory. Int. J. Wildland Fire 2011, 20, 308-317. [CrossRef]

159. Kane, J.M.; Varner, J.M.; Knapp, E.E. Novel Fuelbed Characteristics Associated with Mechanical Mastication Treatments in Northern California and South-Western Oregon, USA. Int. J. Wildland Fire 2009, 18, 686-697. [CrossRef]

160. Liu, X.; Huey, L.G.; Yokelson, R.J.; Selimovic, V.; Simpson, I.J.; Müller, M.; Jimenez, J.L.; Campuzano-Jost, P.; Beyersdorf, A.J.; Blake, D.R.; et al. Airborne Measurements of Western U.S. Wildfire Emissions: Comparison with Prescribed Burning and Air Quality Implications. J. Geophys. Res. 2017, 122, 6108-6129. [CrossRef]

161. Barbero, R.; Abatzoglou, J.T.; Larkin, N.K.; Kolden, C.A.; Stocks, B.J. Climate Change Presents Increased Potential for Very Large Fires in the Contiguous United States. Int. J. Wildland Fire 2015, 24, 892-899. [CrossRef]

162. Spracklen, D.V.; Mickley, L.J.; Logan, J.A.; Hudman, R.C.; Yevich, R.; Flannigan, M.D.; Westerling, A.L. Impacts of Climate Change from 2000 to 2050 on Wildfire Activity and Carbonaceous Aerosol Concentrations in the Western United States. J. Geophys. Res. 2009, 114. [CrossRef] 
163. Liu, Y.; Goodrick, S.L.; Stanturf, J.A.; Future, U.S. Wildfire Potential Trends Projected Using a Dynamically Downscaled Climate Change Scenario. For. Ecol. Manag. 2013, 294, 120-135. [CrossRef]

164. Fox-Hughes, P.; Harris, R.; Lee, G.; Grose, M.; Bindoff, N. Future Fire Danger Climatology for Tasmania, Australia, Using a Dynamically Downscaled Regional Climate Model. Int. J. Wildland Fire 2014, 23, 309-321. [CrossRef]

165. Sharples, J.J.; Cary, G.J.; Fox-Hughes, P.; Mooney, S.; Evans, J.P.; Fletcher, M.-S.; Fromm, M.; Grierson, P.F.; McRae, R.; Baker, P. Natural Hazards in Australia: Extreme Bushfire. Clim. Chang. 2016, 139, 85-99. [CrossRef]

166. De Groot, W.J.; Bothwell, P.M.; Carlsson, D.H.; Logan, K.A. Simulating the Effects of Future Fire Regimes on Western Canadian Boreal Forests. J. Veg. Sci. 2003, 14, 355-364. [CrossRef]

167. Flannigan, M.; Stocks, B.; Turetsky, M.; Wotton, M. Impacts of Climate Change on Fire Activity and Fire Management in the Circumboreal Forest. Glob. Chang. Biol. 2009, 15, 549-560. [CrossRef]

168. Flannigan, M.D.; Krawchuk, M.A.; de Groot, W.J.; Wotton, B.M.; Gowman, L.M. Implications of Changing Climate for Global Wildland Fire. Int. J. Wildland Fire 2009, 18, 483-507. [CrossRef]

169. De Groot, W.J.; Flannigan, M.D.; Cantin, A.S. Climate Change Impacts on Future Boreal Fire Regimes. For. Ecol. Manag. 2013, 294, 35-44. [CrossRef]

170. Turetsky, M.R.; Benscoter, B.; Page, S.; Rein, G.; van der Werf, G.R.; Watts, A. Global Vulnerability of Peatlands to Fire and Carbon Loss. Nat. Geosci. 2015, 8, 11-14. [CrossRef]

171. Yu, Z.C. Northern Peatland Carbon Stocks and Dynamics: A Review. Biogeosciences 2012, 9, 4071-4085. [CrossRef]

172. Page, S.E.; Rieley, J.O.; Banks, C.J. Global and Regional Importance of the Tropical Peatland Carbon Pool. Glob. Chang. Biol. 2011, 17, 798-818. [CrossRef]

173. IPCC. Climate Change 2013: The Physical Science Basis. Contribution of Working Group I to the Fifth Assessment Report of the Intergovernmental Panel on Climate Change; Stocker, T.F., Qin, D., Plattner, G.-K., Tignor, M., Allen, S.K., Boschung, J., Nauels, A., Xia, Y., Bex, V., Midgley, P.M., Eds.; Cambridge University Press: Cambridge, UK; New York, NY, USA, 2013.

174. Turetsky, M.R.; Kane, E.S.; Harden, J.W.; Ottmar, R.D.; Manies, K.L.; Hoy, E.; Kasischke, E.S. Recent Acceleration of Biomass Burning and Carbon Losses in Alaskan Forests and Peatlands. Nat. Geosci. 2011, 4, 27-31. [CrossRef]

175. Laurance, S.G.; Laurance, W.F. Peat Fires: Emissions Likely to Worsen. Nature 2015, 527, 305. [CrossRef]

176. Nepstad, D.C.; Verssimo, A.; Alencar, A.; Nobre, C.; Lima, E.; Lefebvre, P.; Schlesinger, P.; Potter, C.; Moutinho, P.; Mendoza, E.; et al. Large-Scale Impoverishment of Amazonian Forests by Logging And Fire. Nature 1999, 398, 505-508. [CrossRef]

177. Cochrane, M.A.; Alencar, A.; Schulze, M.D.; Souza, C.M.; Nepstad, D.C.; Lefebvre, P.; Davidson, E.A. Positive Feedbacks in the Fire Dynamic of Closed Canopy Tropical Forests. Science 1999, 284, 1832. [CrossRef]

178. Lehsten, V.; Tansey, K.; Balzter, H.; Thonicke, K.; Spessa, A.; Weber, U.; Smith, B.; Arneth, A. Estimating Carbon Emissions from African Wildfires. Biogeosciences 2009, 6, 349-360. [CrossRef]

179. Scholes, R.J.; Archibald, S.; von Maltitz, G. Emissions from Fire in Sub-Saharan Africa: The Magnitude of Sources, their Variability and Uncertainty. Glob. Environ. Res. 2011, 15, 53-63.

180. Nepstad, D.; Carvalho, G.; Cristina Barros, A.; Alencar, A.; Paulo Capobianco, J.; Bishop, J.; Moutinho, P.; Lefebvre, P.; Lopes Silva, U.; Prins, E. Road Paving, Fire Regime Feedbacks, and the Future of Amazon Forests. For. Ecol. Manag. 2001, 154, 395-407. [CrossRef]

181. Cardoso, M.F.; Hurtt, G.C.; Moore Iii, B.; Nobre, C.A.; Prins, E.M. Projecting Future Fire Activity in Amazonia. Glob. Chang. Biol. 2003, 9, 656-669. [CrossRef]

182. Cochrane, M.A.; Barber, C.P. Climate Change, Human Land Use and Future Fires in the Amazon. Glob. Chang. Biol. 2009, 15, 601-612. [CrossRef]

183. Silva, J.M.N.; Carreiras, J.M.B.; Rosa, I.; Pereira, J.M.C. Greenhouse Gas Emissions from Shifting Cultivation in the Tropics, Including Uncertainty and Sensitivity Analysis. J. Geophys. Res. 2011, 116. [CrossRef]

184. Aurell, J.; Gullett, B.K.; Holder, A.; Kiros, F.; Watts, A.; Ottmar, R. Wildland Fire Emission Sampling at Fishlake National Forest, Utah, Using an Unmanned Aircraft System. Atmos. Environ. 2020. submitted.

(C) 2020 by the authors. Licensee MDPI, Basel, Switzerland. This article is an open access article distributed under the terms and conditions of the Creative Commons Attribution (CC BY) license (http://creativecommons.org/licenses/by/4.0/). 